DOI https://doi.org/10.30525/978-9934-26-006-3-12

\title{
EFFECTS OF NATURAL PHENOLIC CARBOXYLIC ACIDS ON WATER FLEA, DAPHNIA MAGNA STRAUS (CLADOCERA)
}

Kudryavtseva D. O.

Graduate Student

Institute of Hydrobiology of National Academy of Science of Ukraine

\section{Mardarevych M. H.} $P h D$,

Research Fellow at the Laboratory of Biologically Active Compounds Institute of Hydrobiology of National Academy of Science of Ukraine

Konovets I. M.

$P h D$, Senior Researcher,

Head of the Laboratory of Biologically Active Compounds

Institute of Hydrobiology of National Academy of Science of Ukraine

Kyiv, Ukraine

A wide variety of biologically active compounds in the aquatic environment (phenols, terpenes, indoles, alkaloids, hydroaromatic compounds, hydrocarbons and others), cause inhibition or stimulation of the functional activity of plant organisms [3, p. 70; 6, p. 61]. In particular, phenolic carboxylic acids (PhCA) demonstrate an endogenous multifunctional bioregulatory effects, which are manifested in cellular signaling, growth processes, the formation of adaptive responses of plants. Such compounds are involved in the processes of respiration, photosynthesis, cell wall formation, light energy transduction, adaptation and protection of plants from many stressors with high growth-regulatory activity. The mode of action of PhCA is associated with changes in structural and functional characteristics that can affect the process of protecting plants from external adverse abiotic and biotic factors in the cellular level [7, p. 28].

It should be noted, that there is no consensus on the mechanisms of action of PhCA on plant organisms yet. Studies on their effects on planktonic invertebrates are virtually absent in the literature.

The list of the most active PhCA includes representatives of both oxycinnamic and oxybenzoic acids - caffeic, coumaric, ferulic, gallic [5, p. 55], as allelochemical agents they cause numerous physiological effects. The aim of this study was to study the effect of low (non-toxic) levels of PhCA on the survival and individual productivity of cladoceran 
Daphnia magna, as well as to identify possible hormesis action of these substances.

The effect of PhCA was studied in the range of concentrations of $0.1-3.2 \mathrm{mg} / \mathrm{L}$ : oxycinnamic - coumaric and caffeic acids, and oxybenzoic - salicylic and gallic acids. The exposure of cladocerans to PhCA concentrations was 21 days, cultivation media were changed twice during this period, on 7th and 14th day. The mortality of animals was recorded and the number of juveniles was counted, the latest were discarded on daily basis. Control and treated animals were fed with mixture of yeast and chlorella three times per week.

Coumaric acid in the range of the studied concentrations $(0.1-3.2 \mathrm{mg} / \mathrm{L})$ causes a negative effect on the fertility of D. magna, which is expressed both in reducing the average number of offspring per female, and increasing the mortality of experimental individuals.

Caffeic acid has multidirectional effects on the productivity of D. magna. On the one hand, a high mortality during the first several days (before reaching the fertile age) has been detected. The mortality of animals was not dose-dependent, indicating the absence of toxic effect in its classical manifestation. On the other hand, the highest values (70-83\% exceeding control) of D. magna fertility were obtained at concentrations $0.4-0.8 \mathrm{mg} / \mathrm{L}$ of caffeic acid in the cultivation medium. It was found significant increasing in productivity of survived and reached reproductive age females owing to increased number of eggs in each brood.

Similar to coumaric, salicylic acid in the range of investigated concentrations shows no stimulating effect the fertility of D. magna, and caused moderate toxic effect on the survival rate of test organisms at the initial exposition period. However, in the both cases, no negative effects were found for offspring, which may indicate the presence of specific and effective mechanisms of planktonic crustaceans adaptation to the increased content of PhCA in the aquatic environment.

Gallic acid at a concentration of $0.8 \mathrm{mg} / \mathrm{L}$ demonstrated a moderate stimulating effect on fertility of D. magna ( $22 \%$ compared to the control).

Obtained data show that the mode of action of PhCA does not depend on their chemical group (oxycinnamic or oxybenzoic). In the range of concentrations of $0.1-0.4 \mathrm{mg} / \mathrm{L}$ (approximately two orders of magnitude lower than the median lethal concentrations), a tendency to moderate negative effects on the early stages of ontogenesis was revealed, which is manifested in increased juvenile mortality (10-30\%) and 1-2 days delay in puberty. The switching to sexual reproduction was not detected. The inconsistency of the registered response pattern to the classical manifestation of toxic action can be explained by the phenomenon of «parental effect». Mechanisms of gaining tolerance in a number of parthenogenetic generations exclude genotypic changes and may consist in the transmission 56 
from the mother of certain factors of activation of enzymatic systems [4, p. 2803], as well as epigenetic changes in the genome, such as methylation of DNA regions or acetylation of histone proteins at the embryonic stage of development [1, p. 900; 2, p. 10121].

\title{
References:
}

1. Alekseev V., Lampert W. Maternal control of resting-egg production in Daphnia. Nature. 2001. Vol. 414. P. 899-901.

2. Jeremias G., Barbosa J., Marques S.M. et al. Transgenerational inheritance of DNA hypomethylation in Daphnia magna in response to salinity stress. Environmental science \& technology. 2018. Vol. 52. Is. 17. P. 10114-10123.

3. Kirpenko N.I., Usenko O.M. Influence of higher aquatic plants on microalgae (a review). Hydrobiol. J. 2013. Vol. 49, No 2. P. 57-74.

4. Ortiz-Rodríguez R., Dao T.S., Wiegand C. Transgenerational effects of microcystin-LR on Daphnia magna. J. Exp. Biol. 2012. Vol. 215. P. 2795-2805.

5. Usenko O.M., Konovets I.N. Analysis of phenolcarbonic acids content in phytomass of higher aquatic plants. Hydrobiol. J. 2014. Vol. 50, No 5. P. 47-60.

6. Usenko O.M., Konovets I.N., Tarashchuk O.S., Gorbunova Z.N. Phenolcarbonic acids of the submerged aquatic plants and their effect on phytoepiphyton structure. Hydrobiol. J. 2019. Vol. 55, No 6. P. 55-64.

7. Usenko O.M., Sakevich O.Y., Balanda O.V. Resistance of algae to biologically active substances. Kyiv: Logos, 2010. 192 p. (in Ukrainian).

DOI https://doi.org/10.30525/978-9934-26-006-3-13

\section{ЕКОЛОГІЧНА ОЦІНКА ДЕНДРОФЛОРИ ПАРКОВОЇ ЕКОСИСТЕМИ «НАТАЛКА» В УМОВАХ УРБОСЕРЕДОВИЩА МІСТА КИЕВА}

\author{
Лавріненко В. М. \\ кандидат біологічних наук, \\ стариий викладач кафедри екологіі \\ Національний педагогічний університет імені М. П. Драгоманова \\ м. Київ, Украӥна
}

Вступ. Паркові екосистеми відіграють важливу роль в архітектурнопланувальній структурі міст. Вони використовуються при формуванні елементів забудови покращуючи середовище життя людей, сприяють 